\title{
A New Principle for the Determination of Total Bacterial Numbers in Populations Recovered from Aerosols
}

\author{
By J. D. ANDERSON* AND G. T. CROUCH \\ Microbiological Research Establishment, Porton, Salisbury, Wiltshire
}

(Accepted for publication 8 November 1966)

\begin{abstract}
SUMMARY
Although the most reliable techniques for determining total bacterial numbers in populations recovered from aerosols are based on radioactive tracers, non-isotopic methods must be used for certain purposes. A tracer technique based on the enzyme galactosidase was developed for the determination of bacterial numbers in samples containing Escherichia coli strain B organisms 1 to $2 \times 10^{7} / \mathrm{ml}$. By using the $\left[{ }^{14} \mathrm{C}\right]$-tracer technique as a reference standard, the enzyme method was shown to be unaffected by the relative humidity at which the aerosol was stored and by the viability of the recovered population and to be scarcely affected by the age of the bacterial cloud. The principle of this method may be applied to other organisms and other suitable enzymes.
\end{abstract}

\section{INTRODUCTION}

Laboratory investigations with pathogenic microbes or simulants can often indicate the importance of aerosols as vehicles for the spread of infections. It is often necessary in laboratory studies to determine total bacterial numbers in populations recovered from aerosols. The concentration of an aerosol and the extent of physical losses due to storage or dilution may then be estimated from total numbers in recovered samples and from the characteristics of the sampling device. The viability of populations recovered from aerosols may also be estimated from the total and viable bacterial numbers in samples. Viability forms a particularly useful measure of the effect of various stresses on survival in the aerosol and may give an indication of the infectivity of a pathogenic microbial aerosol in vivo.

Total bacterial numbers in aerosols may be estimated either by light-scatter measurements on the aerosol itself, or by addition of tracers such as dyes, stable bacterial spores or radioactive materials to the suspension from which the aerosol is generated (methods reviewed by Anderson \& Cox, 1967). Light-scatter methods on the aerosol (e.g. Ferry, Farr, Rose \& Blau, 1951; Dimmick, 1960) have to be calibrated by a tracer method and are susceptible to variations in relative humidity, spray fluids, etc. The dye tracer method (e.g. Ferry et al. 1951; Wolfe, 1961) has the disadvantage that the dye may prove toxic to the organism used, especially since concentration occurs through evaporation of water from aerosol droplets. The dye method has the further disadvantage that when aerosols are generated from bacterial suspensions in water or dilute solutions, particles containing dye alone may be smaller than those containing dye + bacteria and thus have different physical properties. In the spore tracer method the presence of an organism additional to the one under examination may complicate

* Present address: The Medical School, University Walk, Bristol, 2. 
viability determinations and biochemical reactions. There is evidence that the spore tracer in common use, namely Bacillus globigii (B. subtilis var. niger), suffers a rapid initial death in the aerosol (Anderson, 1966; Cox, 1966). Radioactive tracer techniques, although most reliable, cannot be applied when metabolic processes have to be studied with radiotracers subsequent to collection from the aerosol or in cases where expense or health hazards rule out the use of radiotracers. A tracer technique based on an aerostable enzyme has therefore been developed and this paper illustrates the principle using the $\beta$-galactosidase of Escherichia coli strain B.

\section{METHODS}

Organism and media. Cultures of Escherichia coli strain $\mathrm{B}$, were maintained as described by Anderson (1966); likewise the liquid and solid tryptone media and fluids used for the recovery of organisms from aerosols were as described by Anderson (1966).

Growth of organisms. Liquid tryptone medium $(10 \mathrm{ml}$.) supplemented with [U-14 $\mathrm{C}$ ]D-glucose (about $60 \mu \mathrm{g} . / \mathrm{ml}$.; $1.25 \mu \mathrm{C} / \mathrm{ml}$; obtained from the Radiochemical Centre, Amersham, Buckinghamshire) and isopropyl-thio- $\beta$-D-galactopyranoside ( $0.01 \mathrm{mmole} /$ ml.; supplied by Mann Research Laboratories, Inc., New York 6) was inoculated (to $5 \times 10^{7}$ organisms $/ \mathrm{ml}$.) with a suspension of Escherichia coli strain B. After growth in shake culture $\left(100 \mathrm{ml}\right.$. flasks at $37^{\circ}$ for $\left.16 \mathrm{hr}\right)$ the suspensions were stored at room temperature for $2-5 \mathrm{hr}$ before use. The washed bacteria contained about $30 \%$ of the added radiotracer and hydrolysed about $5 \mu$ moles of $o$-nitrophenol- $\beta$-D-galactopyranoside $/ 10^{10}$ organisms/min. in the test described below. Immediately before the generation of an aerosol the organisms were washed once with water by centrifugation then prepared as an aqueous suspension containing about $3 \times 10^{9}$ organisms $/ \mathrm{ml}$.

Generation, storage and recovery of aerosols. Monodisperse aerosols generated in an air-jet atomizer were diluted in a stainless steel tube with a stream of air of controlled water content, to give an atmosphere of the desired relative humidity (Henderson, 1952). Aerosols emerging from the mixing tube could be stored in a rotating stainless steel drum (Goldberg, Watkins, Boerke \& Chatigny, 1958). Aerosol samples were collected into phosphate buffer+alginate (Henderson, 1952) fluid by using a sonic impinger (raised Porton impinger of May \& Harper, 1957) to yield suspensions containing about 1 to $2 \times 10^{7}$ organisms/ml. Further experimental detail was as described previously (Anderson, 1966).

Determination of radioactivity. Apparatus, methods and materials for the determination of radioactivity by a 'coincidence counting' technique with a liquid scintillator were as described by Anderson \& Smith (1965). [ $\left.{ }^{14} \mathrm{C}\right]-$ Determinations had a $95 \%$ confidence belt of $\pm 5 \%$.

Determination of the galactosidase content of bacterial populations. The method used was as described by Anderson (1966) except that bacterial samples were incubated with benzene and $o$-nitrophenol- $\beta$-D-galactopyranoside for $40 \mathrm{~min}$. instead of $30 \mathrm{~min}$. Reagents and containers were preheated in a water bath before addition of bacterial suspensions.

Determinations of viable numbers. Viability was defined as the ability of an organism to produce a visible colony in $18 \mathrm{hr}$ at $37^{\circ}$ on a tryptone agar medium. The culture methods used were as described by Anderson (1966). Colony counts and radioactivity determinations were so arranged that viability estimates had a $95 \%$ confidence belt of $\pm 10 \%$ of observed values. 


\section{RESULTS AND DISCUSSION}

The enzymic activity of the $\beta$-galactosidase of populations of Escherichia coli strain B, recovered from aerosols has been shown to be similar to that of non-sprayed organisms. A limited number of results indicated that the activity of this enzyme was scarcely affected by variations in the viability of recovered organisms or by the relative humidity or storage time of the aerosol. Populations which had been induced to form $\beta$-galactosidase were shown to have similar survival characteristics in the aerosol to normal organisms (Anderson, 1966). If $\beta$-galactosidase were quite stable, and if the enzyme activity and total bacterial count of any suspension were known, then the number of bacteria in populations recovered from aerosols generated from such a suspension could be calculated from the observed galactosidase activity of the recovered population. The reliability of the $\beta$-galactosidase tracer technique was assessed by simultaneously determining total bacterial numbers in a representative array of samples by both the galactosidase and the $\left[{ }^{14} \mathrm{C}\right]$-tracer techniques. In the $\left[{ }^{14} \mathrm{C}\right]$-tracer technique (Anderson, 1966) the test organism itself is labelled under its normal growth conditions with a stable, innocuous and easily determined isotope. At each relative humidity value the $\left[{ }^{14} \mathrm{C}\right]$ content, galactosidase activity and viable count were determined on suspensions taken from the spray pot before and after the experiment, and on samples recovered from aerosols at $1.2 \mathrm{sec}$., $5 \mathrm{~min}$., $15 \mathrm{~min}$. and $30 \mathrm{~min}$. after generation.

Table 1. Evidence for the reliability of the galactosidase tracer technique for the determination of total bacterial numbers in populations recovered from aerosols of Escherichia coli strain $B$.

\begin{tabular}{ccc} 
& \multicolumn{2}{c}{$\begin{array}{c}\text { Mean* } \begin{array}{c}\text { (and } 95 \% \text { fiducial limits of mean) } \\
\text { value for the ratio: }\end{array} \\
\text { bacterial numbers by galactosidase method }\end{array}$} \\
\cline { 2 - 3 } $\begin{array}{c}\text { Age of aerosol cloud } \\
\text { bacterial numbers by }\left[{ }^{14} \mathrm{C}\right]-\text { tracer method }\end{array}$ & $(94 \cdot 6 \rightarrow 100$ \\
$\begin{array}{c}\text { Unsprayed control removed } \\
\text { from spray pot after each } \\
\text { experiment }\end{array}$ & 98.1 & \\
$1.2 \mathrm{sec}$. & & $(94 \cdot 1 \rightarrow 104 \cdot 6)$ \\
$5 \mathrm{~min}$. & 99.3 & $(98.5 \rightarrow 106.0)$ \\
$15 \mathrm{~min}$. & 102.2 & $(100.9 \rightarrow 110.0)$ \\
$30 \mathrm{~min}$. & 105.4 & $(101 \cdot 1 \rightarrow 110.8)$
\end{tabular}

* Each value the mean of twenty determinations over a range of relative humidities from 32 to $93 \%$. This ratio was given the value of $100 \%$ in unsprayed controls removed from the spray pot before each experiment.

Estimates of total bacterial numbers by the galactosidase method were found to be similar to those determined by the $\left[{ }^{14} \mathrm{C}\right]$ method over a whole range of relative humidity values and aerosol ages. For each bacterial suspension the sample size determined by the galactosidase method was expressed as a percentage of that obtained by the radiotracer method; this ratio was then used in a statistical analysis of results. There was no significant correlation between this ratio and the relative humidity at which the aerosol was held. Table 1 provides evidence that this ratio tended to increase with increasing aerosol age. This increase, which was comparatively trivial, amounted to about $6 \%$ over $30 \mathrm{~min}$. and might be an artifact caused by the increased accessibility 
of the enzyme to the test substrate in thoroughly dried bacteria. Combined results of all 80 determinations on samples recovered from aerosols confirmed that there was a small significant correlation (correlation coefficient $0.24 ; P=3 \%$ ) between aerosol age and the ratio of total bacterial numbers determined by the two methods. If the $\left[{ }^{14} \mathrm{C}\right]$ technique is regarded as a reference standard, bacterial numbers may be obtained within about $2 \%$ of true values by dividing observed values obtained by the galactosidase method by a factor of $\left(1.0065+0.000035 T_{s}\right)$, where $T_{s}$ is the aerosol age in seconds. Such accuracy is seldom required in aerosol studies. There was no significant correlation between the galactosidase/radiotracer ratio and the viability of recovered populations ( 80 samples covering a range of viabilities from 2 to $100 \%$ with a mean of $30 \%$ ).

The extremely close agreement between these two tracer methods which depend upon different principles and techniques shows that the galactosidase tracer method is entirely reliable for Escherichia coli strain B. The principle of tracing aerosols with enzymes could be applied to other organisms and other enzyme systems, e.g. the high catalase content of many organisms and the sensitivity of assay methods for this enzyme suggests an alternative approach for certain other bacteria.

We are most grateful to $\mathrm{Mr}$ I. H. Silver for his encouragement and discussions and to $\mathrm{Mr}$ S. Peto for statistical analysis and for his advice.

\section{REFERENCES}

Anderson, J. D. (1966). Biochemical studies of lethal processes in aerosols of Escherichia coli. J. gen. Microbiol. 45, 303.

Anderson, J. D. \& Cox, C. S. (1967). Microbial Survival. Symp. Soc. gen. Microbiol. $17,203$.

Anderson, J. D. \& SMITH, H. (1965). The metabolism of erythritol by Brucella abortus. J. gen. Microbiol. 38, 109.

Cox, C.S. (1966). The survival of Escherichia coli sprayed into air and into nitrogen from distilled water and from solutions of protecting agents as a function of relative humidity. J. gen. Microbiol. 43, 383.

Dimmick, R. L. (1960). Measurement of the physical decay of aerosols by a light scatter method compared to a radioactive tracer method. J. Hyg., Camb. 58, 373.

Ferry, R. M., FARr, L. E., Rose, J. \& BlaU, M. R. (1951). A study of freshly generated aerosols of Micrococcus candidus and Escherichia coli. J. infect. Dis. 88, 256.

Goldberg, L. J., Watkins, H. M. S., BoeRke, E. E. \& Chatigny, M. A. (1958). The use of a rotating drum for the study of aerosols over extended periods of time. Am. J. Hyg. 68, 85.

HeNDERSON, D. W. (1952). An apparatus for the study of airborne infection. J. Hyg., Camb. $50,53$.

MAY, K. R. \& HARPER, G. J. (1957). The efficiency of various liquid impinger samplers for bacterial aerosols. Br. J. ind. Med. 14, 287.

WolfE, E. K. (1961). Quantitative characterisation of aerosols. Bact. Rev. 25, 194. 